\title{
PERAN KEPUASAN KONSUMEN MEMEDIASI PENGARUH HARGA TERHADAP LOYALITAS KONSUMEN DALAM BERBELANJA CLOTHING ONLINE MELALUI INSTAGRAM
}

\author{
Ni Luh Putu Anindya Putri Maharani' \\ Ni Wayan Ekawati
}

1,2 Fakultas Ekonomi dan Bisnis Universitas Udayana (Unud), Bali, Indonesia email : anindyaputri293@yahoo.com

\begin{abstract}
ABSTRAK
Tujuan penelitian ini untuk menjelaskan kepuasan konsumen dan harga sebagai prediktor terhadap loyalitas konsumen dalam berbelanja clothing online di Kota Denpasar. Pengumpulan data ini menggunakan kuesioner dengan teknik purposive sampling pada 88 responden di Kota Denpasar, terdapat 11 indikator dan menggunakan metode analisis path. Hasil menunjukkan bahwa harga berpengaruh positif dan signifikan terhadap kepuasan konsumen dan loyalitas konsumen pada clothing online, kepuasan konsumen mampu memediasi. Data responden yang secara langsung dapat dilihat yaitu harga memiliki pengaruh positif dan signifikan terhadap loyalitas pelanggan, harga memiliki pengaruh positif dan signifikan terhadap kepuasan pelanggan, kepuasan pelanggan memiliki pengaruh positif dan signifikan terhadap loyalitas pelanggan, kepuasan pelanggan berperan sebagai variabel intervening antara harga dan loyalitas pelanggan.
\end{abstract}

Kata Kunci : kepuasan konsumen, harga dan loyalitas konsumen

\section{ABSTRACT}

The purpose of this study is to explain customer satisfaction and prices as predictors of consumer loyalty in shopping for clothing online in the city of Denpasar. This data collection uses a questionnaire with purposive sampling technique on 88 respondents in Denpasar City, there are 11 indicators and use the Path analysis method. The results show that prices have a positive and significant effect on consumer satisfaction and consumer loyalty to clothing online, customer satisfaction is able to mediate. Respondent data that can be directly seen is that prices have a positive and significant influence on customer loyalty, prices have a positive and significant influence on customer satisfaction, customer satisfaction has a positive and significant influence on customer loyalty, customer satisfaction acts as an intervening variable between price and customer loyalty .

Keywords: consumer satisfaction, price and consumer loyalty 


\section{PENDAHULUAN}

Dewasa ini persaingan dalam dunia bisnis berkembang pesat. Persaingan yang pesat ini menuntut bisnis untuk memaksimalkan pengoperasian perusahaannya agar bisa bersaing di pasar. Munculnya persaingan dalam dunia bisnis baik dalam industri kecil, menengah dan skala besar adalah salah satu yang tidak dapat dihindari. Persaingan adalah keadaan dimana perusahaan pada pasar produk atau jasa tertentu akan memperlihatkan keunggulannya masing-masing, dengan atau tanpa terikat peraturan tertentu dalam rangka meraih pelanggan (Setyawati dan Rosiana, 2015). Aktivitas inovasi yang kreatif baik itu inovasiproses maupun inovasi produk akan meningkatkan kemampuan perusahaan menciptakanproduk yang berkualitas selanjutnya diharapkan akan meningkatkan keunggulan bersaing perusahaan yang pada akhirnya berdampak pada kinerja perusahaan (Ekawati et al., 2016).

Sebagian besar dunia bisnis saat ini dilaksanakan di jaringan digital yang menghubungkan orang dan perusahaan. Pengguna internet di Indonesia menggunakan jejaring sosial tidak hanya berfungsi sebagai bersosialisasi dengan teman, keluarga dan mencari teman baru namun, juga sebagai promo/jualan danmencari kerja (Ipsos-na, 2012). Perkembangan penggunaan internet saat ini mendorong adanya suatu potensi besar terciptanya online shopping. Online shoping telah menjadi fenomena pada saat ini karena dinilai lebih praktis.

Perkembangan internet yang pesat di Indonesia memberikan kontribusi yang besar bagi penggunanya terutama dalam dunia bisnis. Jumlah pengguna internet di Indonesia setiap tahunnya terus mengalami peningkatan, salah 
satunya adalah di Kota Denpasar hal ini menjadi peluang yang besar dalam dunia bisnis online dengan tumbuhnya toko-toko berbasis internet yang sering disebut toko online (Demirci et al., 2008). Terlihat dari data pengguna internet di Provinsi Bali (dalam persentase) pada tahun 2015-2017.

Pada Tabel 1. menunjukkan melalui hasil data pengguna internet di Provinsi Bali yang dimuat oleh Badan Pusat Statistik Provinsi Bali tersebut dapat dilihat bahwa pengguna internet di Kota Denpasar selalu menempati urutan pertama pada tahun 2015 - 2017. Terlihat dari tabel pengguna internet, di Kota Denpasar yang mengakses Internet lebih banyak dari Kabupaten/Kota lainnya. Jumlah pengguna internet dilihat secara geometris dan banyak orang yang lebih ingin menggunakan internet untuk mencari informasi produk saat itulah online shop berada di puncaknya menurut (Schiffman dan Kanuk, 2008:265). Sebagian besar konsumen merasa mendapatkan informasi lebih banyak dengan melakukan penelusuran online daripada harus bertemu langsung dengan pelayan toko. Melalui alat komunikasi elektronik atau jejaring sosial di mana konsumen tidak perlu susah payah datang ke toko untuk melihat dan membeli karena, dengan adanya belanja online konsumen hanya tinggal melihat barang yang diinginkan di internet kemudian memesan barang sesuai pilihan dan mentransfer uangnya lalu barang dikirim oleh toko online dan sampai kerumah (Meskaran et al., 2013).

Salah satu media sosial yang sedang berkembang sangat cepat saat ini adalah Instagram (Wagner, 2015). Instagram merupakan satu-satunya media online yang terprotek dalam penyimpanan foto yang ada di dalamnya, sehingga menyulitkan pihak lain untuk melakukan penduplikasian. Berjualan lewat Instagram sangat 
mudah dan cepat, para pebisnis lebih mudah memasarkan produknya melalui media Instagram karena targetnya adalah orang yang dekat dengannya, bisa juga teman dari teman yang mem-follow kita, atau teman kita yang dari mulut ke mulut (word of mouth) menceritakan pengalaman berbelanjanya pada kerabat sambil menunjukkan akun Instagram tempat mereka berbelanja secara online.

Tabel 1.

Data Pengguna Internet di Provinsi Bali

\begin{tabular}{lccc}
\hline \multirow{2}{*}{ Kabupaten/Kota } & \multicolumn{3}{c}{ Tahun } \\
\cline { 2 - 4 } Jembrana & $\mathbf{2 0 1 5}$ & $\mathbf{2 0 1 6}$ & $\mathbf{2 0 1 7}$ \\
Tabanan & $17,15 \%$ & $22,56 \%$ & $28.27 \%$ \\
Badung & $25.06 \%$ & $28,40 \%$ & $32.71 \%$ \\
Gianyar & $36,82 \%$ & $43,98 \%$ & $54.62 \%$ \\
Klungkung & $26,90 \%$ & $34,20 \%$ & $39.76 \%$ \\
Bangli & $18,76 \%$ & $22,34 \%$ & $26.82 \%$ \\
Karangasem & $18,65 \%$ & $24,73 \%$ & $25.15 \%$ \\
Buleleng & $14,82 \%$ & $16,85 \%$ & $22.73 \%$ \\
Denpasar & $17,40 \%$ & $21,31 \%$ & $24.75 \%$ \\
& $49,38 \%$ & $54,46 \%$ & $59.78 \%$ \\
\hline Total & & & \\
\hline
\end{tabular}

Sumber : Badan Pusat Statistik Bali, 2017

Para konsumen pun bisa dengan mudah dan cepat menemukan produk yang diinginkan. Komunikasi pemasaran seperti inilah yang menunjang prosesnya berjualan di Instagram. Komunikasi pemasaran yang baik bisa mengarahkan calon pembeli hingga menjadi pembeli pada akhirnya(Mira Witriyanti, 2015). Beranjak dari hal tersebut untuk mengetahui seberapa besar media sosial yang sering 
digunakan para konsumen di Indonesia, maka bisa dilihat pada gambar sebagai berikut.

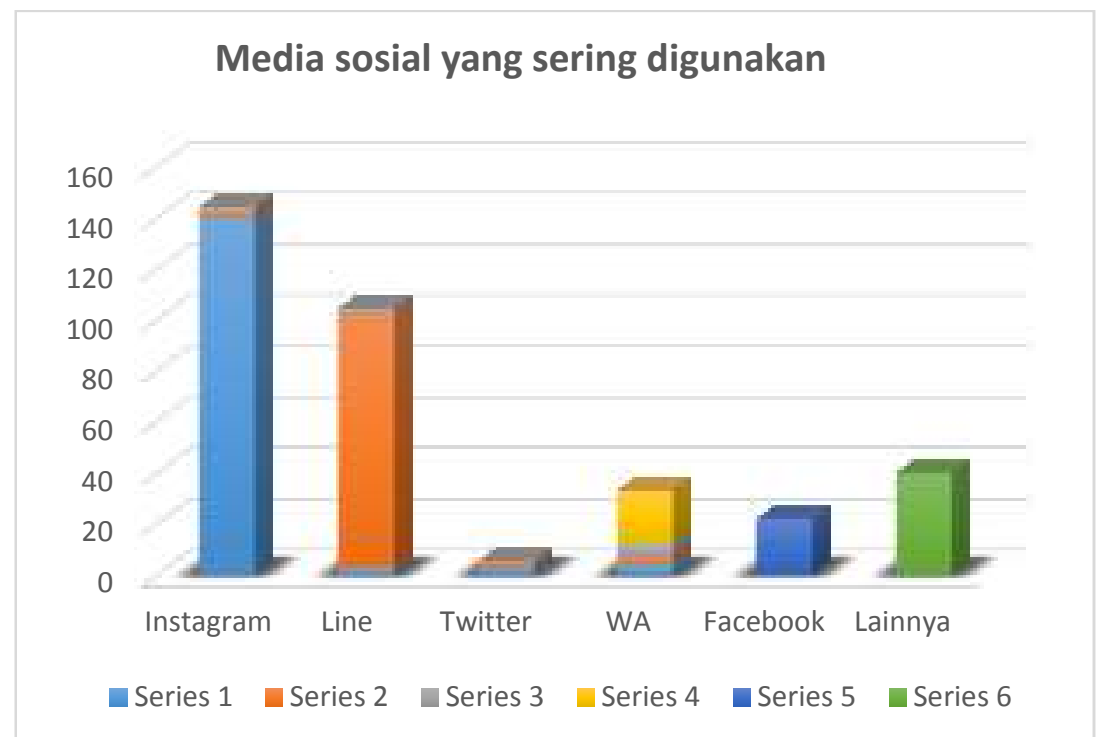

Gambar 1. Media Sosial yang sering digunakandi Indonesia Sumber: Rustiana, 2018

Gambar 1. menunjukan informasi tentang media sosial yang sering digunakan para responden.Instagram 40\% (142 orang), Line 32\% (112 orang), Whatsapp 9\% (32 orang), Facebook $7 \%$ (25 orang), media sosial lainnya (Path, Youtube, dan Blackberry Messanger) $11 \%$ (40 orang), dan Twitter 1\% (3 orang). Gambar tersebut juga menunjukkan informasi tentang tiga jenis media sosial (Instagram, Line, dan Whatsapp) yang paling efektif (indikator dari frekuensi penggunaan) untuk tujuan bisnis dan social (Rustiana, 2018). Jika dibandingkan dengan media sosial yang lain seperti Facebook, Instagram memiliki beberapa kelebihan. Menurut Rocketmanajemen (2016) mengungkapkan beberapa kelebihan dan kekurangan dari Facebook dan Instagram sebagai alat pemasaran adalah melalui Facebook kita dapat berbagi info apapun namun terkadang info tersebut sangat panjang dan menyulitkan pengguna memahaminya. Pada Instagram info dapat dibagikan walau 
hanya melalui foto selain itu, Facebook juga efektif apabila digunakan sebagai ajang promosi dan iklan karena penggunanya sangat banyak. Sedangkan Instagram juga efektif digunakan sebagai ajang promosi iklan karena memiliki fitur hastag yang memudahkan untuk pengelompokan jenis.

Loyalitas adalah sikap konsumen yang positif kepada sebuah merek, di mana konsumen mempunyai keinginan kuat untuk membeli kembali sebuah merek yang sama (Sunyoto, 2014:142). Loyalitas akan muncul jika konsumen mendapatkan apa yang mereka inginkan sehingga setelah mereka menggunakan produk tersebut mereka akan mendapatkan pengalaman yang akan mendorong mereka untuk melakukan pembelian secara berulang dan pada akhirnya timbul rasa loyal terhadap produk tersebut.Loyalitas pelanggan tercipta melalui kepuasan pelanggan atas produk yang dikonsumsi, dimana pelanggan merasa harapannya terpenuhi sehingga mengarah kepada loyalitas pelanggan (Tjiptono, 2006:110 ).

Mempertahankan loyalitas pelanggan menjadi kewajiban yang harus diutamakan daripada mendapatkan pelanggan baru. Sangat penting dalam sebuah usaha bisnis untuk bisa membangun, mempertahankan hingga meningkatkan loyalitas pelanggannya, suatu perusahaan dapat dikatakan tidak dapat bertahan dalam mengahadapi pesaing bilamana loyalitas pelanggan tidak ada. Oleh sebab itu, dengan memberikan kepuasan pelanggan dapat meningkatkan loyalitas pelanggan suatu perusahaan (Amir, 2013).

Kepuasan konsumen adalah kunci dalam membuat konsumen loyal. Banyak manfaat yang diterima oleh perusahaan dengan tercapainya tingkat kepuasan pelanggan yang tinggi dan perasaan seseorang yang puas atau sebaliknya setelah 
membandingkan antara kenyataan dan harapan yang diterima dari sebuah produk atau jasa (Kotler, 2007:36).Setelah mengkonsumsi suatu produk atau jasa, konsumen akan memiliki perasaan puas atau tidak puas terhadap produk atau jasa yang dikonsumsinya, dari sinilah tingkat kepuasan konsumen tercipta(Sangadji dan Sopiah, 2013:190).

Kepuasan konsumen dalam melakukan transaksi online shopping di indikasi berpengaruh terhadap kepercayaan konsumen yang pada akhirnya akan berpengaruh sikap konsumen dalam melakukan pembelian ulang (Elvandari, 2011). Kepuasan konsumen pada E-commerce merupakan faktor yang terpenting bagi kelangsungan hidup pada toko online, jika seseorang yang berbelanja pada situs online merasa puas maka bisa dikatakan toko online tersebut berhasil dan dapat memperoleh pelanggan yang loyal terhadap situs online tersebut.(Oliver dalam Onyancha, 2013) menyatakan bahwa kepuasan pelanggan dapat didefinisikan sebagai harapan sebelum pembelian dan persepsi tentang kinerja setelah pembelian. Pada pembelian online kepuasan tersebut dapat dicapai dengan memberikan harga yang terjangkau kepada konsumen sehingga konsumen dalam berbelanja online akan puas dengan harga tersebut.

Harga merupakan sejumlah uang yang akan ditukarkan oleh sebuah produk atau jasa. Harga adalah sejumlah nilai yang konsumen tukarkan untuk manfaat dalam menggunakan suatu barang atau jasa (Kotler dan Armstrong, 2013). Harga adalah satuan moneter atau ukuran lainnya (termasuk barang dan jasa lainnya) yang ditukarkan agar memperoleh hak kepemilikan atau penggunaan suatu barang dan jasa sehingga menimbulkan kepuasan konsumenmenurut (Buchari, 
2011:169).Harga juga mempunyai bauran penting dalam pemasaran suatu produk yang membuat harga mengandung utilitas atau kegunaan tertentu yang diperlukan untuk mendapatkan suatu jasa (Fandy Tjiptono, 2016:192-193).

Harga dari suatu barang akan dapat menentukan kualitas dari barang tersebut. Hal ini terlihat bahwa barang yang mempunyai harga mahal dapat menunjukkan bahwa kualitas barang tersebut lebih baik. Menurut (Kartono, 2010:97) menyatakan bahwa keunikan produk adalah supplier yang memproduksi produk yang sangat spesifik agar perusahaan memiliki posisi tawar yang lebih tinggi dibandingkan dengan perusahaan yang produknya merupakan produk komoditas. Suatu barang dengan harga yang mahal juga menunjukkan bahwa barang tersebut memiliki ciri khas yang membedakan dengan barang lainnya yang sejenis. Ketika harga yang diberikan baik tinggi atau rendah namun tetap dibarengi dengan pengharapan yang tinggi maka pelanggan akan merasakan suatu kepuasan terhadap produk tersebut. Pelanggan dapat beralih ke merek lain apabila harga yang ditentukan tidak sesuai dengan manfaat yang pelanggan terima sehingga membuat pelanggan tidak puas.

Berdasarkan research gap antara variabel kepuasan pelanggan meningkat dengan persepsi harga produk yang murah. Dibuktikan melalui penelitian yang dilakukan Noor Hafiza (2017) yang menunjukkan hasil bahwa persepsi harga adalah faktor paling signifikan terhadap kepuasan pelanggan. Hasil yang sama juga dibuktikan melalui penelitian terdahulu yang menunjukkan bahwa persepsi harga dan kepuasan pelanggan dapat berpengaruh secara signifikan dan positif (Ismail, 2016; Sedjai et al. 2018). Namun, penelitian yang telah dilakukan Amir et al. (2013) yang berjudul “The Effect of Service Quality and Price on Satisfaction and Loyalty 
of Customer of Commercial Flight Service Industry" menunjukkan hasil negatif dan tidak signifikan antara variabel harga terhadap kepuasan konsumen tetapi memiliki pengaruh yang positif dan signifikan terhadap loyalitas konsumen.

Di Kota Denpasar untuk mengetahui seberapa besar minat yang dimiliki konsumen dalam melakukan pembelianclothing online, maka dilakukanlah penelitian dengan menggunakan metode pra survei dengan menyebarkan kuisioner sementara kepada 35 orang responden.

Hasil pra-survei seluruh responden, sudah pernah melalukan pembelian dalam clothing onlinemelalui Instagram dan puas terhadap service clothing online karena pemesanan melalui admin dengan respon yang cepat dan sangat ramah. Pada pernyataan ini 25 dari 30 responden menjawab sangat setuju, dan 10 orang menjawab setuju. Sehingga dapat disimpulkan bahwa kepuasan konsumen terhadap clothing online sangat tinggi. Dalam pra survei, peneliti menanyakan dari tiga dimensi tersebut dimensi apa yang menjadi alasan utama mereka berbelanja clothing online melalui Instagram. Pra survei didapatkan sebagaian besar responden mengangap bahwa loyalitas konsumen dipengaruhi oleh kepuasan konsumen dan harga yang mereka rasakan setelah berbelanja pada clothing online melalui Instagram. Namun, karena perkembangan media sosial saat ini sangat pesat yang menyebabkan semakin banyaknya pesaing hal ini menyebabkan kepuasan konsumen dan harga yang dirasakan dapat berkurang.

Harga merupakan peran strategik dalam pemasaran. Harga merupakan satuan moneter atau ukuran lainnya (termasuk barang dan jasa lainnya) yang ditukarkan agar memperoleh hak kepemilikan atau penggunaan suatu barang atau jasa (Fandy 
Tjiptono, 2016:290). Harga merupakan salah satu cara untuk mendorong minat konsumen untuk melakukan pembelian. Perbedaan layanan yang dirasakan dapat menimbulkan kewajaran harga di benak konsumen, kewajaran harga yang dirasakan akan menimbulkan niat beli yang akan membentuk keputusan membeli (Atmaja, 2011). Bagi konsumen, harga sangat mempengaruhi kualitas barang dan keputusan pembelian karena banyak orang menganggap bahwa barang yang memiliki kualitas baik, maka untuk memperolehnya pun tidak sedikit yang kita korbankan karena harganya pasti sangat tinggi.

Secara umum kepuasan adalah perasaan senang atau kecewa seseorang yang muncul setelah membandingkan kinerja (hasil) produk yang dipikirkan terhadap kinerja (atau hasil) yang diharapkan (Kotler dan Keller, 2007:177). Kepuasan tercipta ketika perusahaan dapat memenuhi kebutuhan konsumen dengan baik (Moraga et al., 2008). Kepuasan adalah tanggapan konsumen atas terpenuhinya kebutuhannya. Hal itu berarti penilaian bahwa suatu bentuk keistimewaan dari suatu barang atau jasa ataupun barang/jasa itu sendiri, memberikan tingkat kenyamanan yang terkait dengan pemenuhan suatu kebutuhan, termasuk pemenuhan kebutuhan di bawah harapan atau pemenuhan kebutuhan melebihi harapan pelanggan. Seorang konsumen, jika merasa puas dengan kinerja (hasil) produk yang dipikirkan, sangat besar kemungkinannya menjadi konsumen dalam waktu yang lama (Kotler, 2011:70).

Loyalitas konsumen merupakan tindakan konsumen untuk membeli rutin dan didasarkan pada unit pengambilan keputusan (Sangadji dan Sopiah, 2013:105). Konsumen dengan loyalitas merupakan pembeli yang mempertahankan sikap 
Ni Luh Putu Anindya Putri Maharani, Peran Kepuasan Konsumen....

positif terhadap produk atau jasa (Sari, 2014). Loyalitas konsumen adalah pembelian ulang suatu merek secara konsisten oleh konsumen (Tjiptono, 2011:485). Loyalitas merek pada konsumen terjadi karenaadanya pengaruh kepuasan dan ketidakpuasan dengan merek tersebut yang terakumulasikan secara terus-menerus, di samping adanya persepsi kualitas produk (Hasan, 2012: 83). Memiliki konsumen yang loyal adalah suatu tujuan akhir dari perusahaan, karena loyalitas konsumen dapat menjamin kontinuitas perusahaan dalam jangka panjang. Pada dasarnya loyalitas konsumen dapat diartikan sebagai kesetiaan seseorang terhadap suatu hal. Istilah loyalitas konsumen sebetulnya berasal dari loyalitas merek yang mencerminkan loyalitas konsumen pada merek tertentu.

Hasil penelitian yang menyatakan bahwa terdapat pengaruh positif antara harga terhadap loyalitas pelanggan supermarket Sri Ratu Peterongan, populasi dalam penelitian ini adalah seluruh pelanggan supermarket Sri Ratu Peterongan, sampel dalam penelitian ini berjumlah 100 orang, teknik analisis data yang digunakan yaitu analisis regresi linier berganda Bebet Wijayanto (2013).

Berdasarkan penelitian semakin harga suatu produk atau jasa sesuai dengan kualitas suatu produk atau jasa tersebut maka kepuasan yang dirasakan pelanggan akan semakin tinggi dan semakin loyal pelanggan tersebut. Penelitian ini dilakukan di Semarang, yang dimana sampel berjumlah 100 orang. Berdasarkan hasil penelitian sebelumnya, maka dapat disusun hipotesis sebagai berikut.

$\mathrm{H}_{1}$ :Harga berpengaruh positif dan signifikan terhadap loyalitas pelanggan berbelanja melalui Instagram padaclothing online diKota Denpasar.

Hasil penelitian yang dilakukan oleh Albertus (2012) menyatakan adanya pengaruh harga terhadapkepuasan konsumen dengan hasil yang mengatakan bahwa 
konsumen puas dengan harga yang relatif tidak murah namun sesuai dengan kualitas dari produk tersebut. Penelitian yang dilakukan oleh (Aprilia, 2013) juga menyatakan bahwa harga berpengaruh positif terhadap kepuasan pelanggan.

Hasil penelitian yang dilakukan oleh (Wahyuno, 2013) tentang pengaruh kualitas pelayanan dan harga terhadap kepuasan konsumen pengguna jasa Hotel Anugerah Glagah Indah Temon Kulon Progo Yogyakarta. Hasil penelitian menunjukkan bahwa kualitas pelayanan dan harga berpengaruh positif dan signifikan secara parsial dan simultan terhadap kepuasan konsumen di Hotel Anugerah Glagah Indah. Berdasarkanhasil dari penelitian sebelumnya, maka dapat disusun hipotesis sebagai berikut.

$\mathrm{H}_{2}$ :Harga berpengaruh positif dan signifikan terhadap kepuasan konsumen berbelanja melalui Instagrampada clothing online di Kota Denpasar.

Hasil penelitian yang menyatakan bahwa kepuasan pelanggan berpengaruh terhadap loyalitas pelangganyang dilakukan oleh (Ashgarian et al., 2012) menyatakan bahwa kepuasan pelanggan berpengaruh positif terhadap loyalitas pelanggan. Di dalam jurnal ini meneliti tentang kualitas produk, citra perusahaan, kepuasan konsumen dan loyalitas konsumen hijau.

Konsumen akan setia atau loya lterhadap suatu merek bila konsumen mendapatkan kepuasan dari merek tersebut. Meningkatkan kepuasan pelanggan,perusahaan tersebut perlu mengatur strategipemasaran agar konsumen tertarik terhadapproduk-produk yang ditawarkan. Apabila produk tersebut memberi kepuasan bagi konsumen, maka konsumen akan tetap setiamenggunakan merek tersebut dan berusahauntuk membatasi pembelian produk lain (Aryani dan Rosinta, 2010). Pelanggan yang sangat puas atau bahkan menyenangi layanan cenderung 
menjadi pendukung loyal perusahaan dan menyebar berita positif. Ketidakpuasan sebaliknya menjauhkan pelanggan dan menjadi faktor penentu dalam perilaku beralih(Lovelock et al., 2013). Berdasarkan hasil penelitian sebelumnya, maka dapat disusun hipotesis sebagai berikut.

$\mathrm{H}_{3}$ : Kepuasan pelanggan berpengaruh positif dan signifikan terhadap loyalitas pelanggan berbelanja melalui Instagram pada clothing online di Kota Denpasar.

Menurut (Subagio dan Harianto, 2013) menyebutkan bahwa faktor yang memepengaruhi kepuasan dan loyalitas pelanggan adalah brand dan harga. Hasil penelitian yang menyatakan tentang pengaruh harga dan kualitas pelayanan terhadap loyalitas pelanggan melalui variabel kepuasan (Kurniasih, 2012). Penelitian ini dilakukan di Siliwangi, Semarang dengan jumlah populasi sebanyak 18.123 pelanggan.

Hasil penelitian yang meneliti tentang analisis pengaruh kualitas pelayanan, harga dan kepuasan pelanggan terhadap loyalitas pelanggan. Penelitian ini dilakukan di Semarang dengan jumlah populasi pelanggan tetap yang dimiliki pada periode tahun 2009-2011 adalah sebanyak 115 pelanggan (Febri dan Edy, 2012). Jadi, dari penelitian sebelumnya ditemukan bahwa harga berpengaruh terhadap loyalitas, harga berpengaruh terhadap kepuasan konsumen dan kepuasan konsumen berperan sebagai variabel intervening antara harga dan loyalitas pelanggan. Berdasarkan hasil penelitian sebelumnya, maka dapat disusun hipotesis sebagai berikut.

$H_{4}$ : Kepuasan konsumen secara positif dan signifikan memediasi pengaruh harga dan loyalitas konsumen dalam berbelanja pada clothing online di Kota Denpasar. 


\section{METODE PENELITIAN}

Penelitian ini menggunakan penelitian kausal untuk bisa menjelaskan hubungan sebab-akibat antara variabel-variabel penelitian yang terdiri atas harga, kepuasan konsumen, dan loyalitas konsumen. Lokasi penelitian ini dilakukan di Kota Denpasar dengan obyek penelitian adalah variabel kepuasan konsumen, harga dan loyalitas konsumen dengan mengambil studi pada clothing online di Kota Denpasar.

Tabel 2.

Klasifikasi Variabel dan Indikator Penelitian

\begin{tabular}{|c|c|c|c|}
\hline $\begin{array}{c}\text { Klasifikasi } \\
\text { Variabel }\end{array}$ & Variabel & Indikator & Sumber \\
\hline Eksogen & $\begin{array}{l}\text { Harga } \\
(\mathrm{X})\end{array}$ & 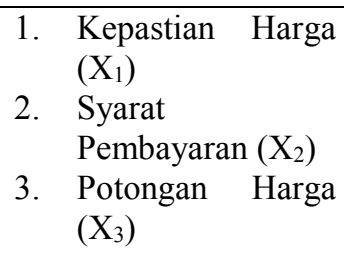 & $\begin{array}{l}\text { Kotler dan } \\
\text { Amstrong } \\
(2012: 52), \text { Farhan } \\
(2014: 42)\end{array}$ \\
\hline Mediasi & $\begin{array}{l}\text { Kepuasan } \\
\text { Konsumen (M) }\end{array}$ & $\begin{array}{lll}\text { 1. } & \begin{array}{l}\text { Kualitas } \\
\left(\mathrm{M}_{1}\right)\end{array} \\
\text { 2. } & \begin{array}{l}\text { Service } \\
\left(\mathrm{M}_{2}\right)\end{array} \\
\text { 3. } & \text { Emotional } \\
& \left(\mathrm{M}_{3}\right) & \text { Factor } \\
\text { 4. } & \text { Harga }\left(\mathrm{M}_{4}\right) \\
\text { 5. } & \text { Biaya }\left(\mathrm{M}_{5}\right)\end{array}$ & $\begin{array}{l}\text { Daryanto dan } \\
\text { Setiyobudi } \\
(2014: 53-54)\end{array}$ \\
\hline Endogen & $\begin{array}{l}\text { Loyalitas } \\
\text { Konsumen (Y) }\end{array}$ & $\begin{array}{ll}\text { 1. } & \text { Pembelian } \\
\text { berulang }\left(\mathrm{Y}_{1}\right) \\
\text { 2. } & \text { Penilaian terhadap } \\
\text { produk }\left(\mathrm{Y}_{2}\right) \\
\text { 3. }\end{array}$ & $\begin{array}{l}\text { Kottler dan Keller } \\
(2012: 57)\end{array}$ \\
\hline
\end{tabular}


Ni Luh Putu Anindya Putri Maharani, Peran Kepuasan Konsumen....

Populasi adalah adalah masyarakat yang berdomisili di Kota Denpasar yang sudah pernah berbelanja di Instagram lebih dari satu kali. Penelitian ini menggunakan sampel sebanyak 88 responden dari Kota Denpasar. Penelitian ini menggunakan 88 sampel yang berarti sudah memenuhi kriteria yaitu minimal 55 dan maksimal 110. Teknik pengambilan sampel yang digunakan pada penelitian iniadalah non probability samplingyaitu teknik pengambilan sampel yang tidak memberi peluang/kesempatan yang sama bagi setiap unsur atau anggota populasi untuk dipilih menjadi sampel (Rahyuda, 2016:172).

Teknik penentuan sampel yang digunakan dalam penelitian ini adalah purposive sampling, yaitu sampel ditentukan dengan pertimbangan tertentu (Sugiyono, 2017:85 ). Metode pengumpulan data dalam penelitian ini dikumpulkan melalui kuesioner yang berupa pernyataan kepada responden.Penyebaran kuesioner, dilakukan dengan dua cara, yaitu dikirim ke email atau line konsumen dan secara konvensional. Pengukuran atas jawaban dari responden diukur dengan menggunakan skala Likert. Berdasarkan sumbernya, data yang digunakan dalam penelitian ini adalah data primer dandata sekunder. Pada penelitian ini digunakan jenis data menurut sifatnya yaitu data kuantitatif dan data kualitatif.

Penelitian ini menggunakan analisis jalur atau path analysis untuk mencari tahu hubungan antara variabel yang satu terhadap variabel yang lainnya. Serta menggunakan uji sobel untuk menguji hipotesis mediasi. Merumuskan hipotesis dan persamaan structural :

a) Persamaan Sub-struktural 1

$\mathrm{M}=\beta_{1} \mathrm{X}+\mathrm{e}_{1}$

b) Persamaan Sub-struktural 2 $\mathrm{Y}=\beta_{1} \mathrm{X}+\beta_{2} \mathrm{M}+\mathrm{e}_{2}$ 


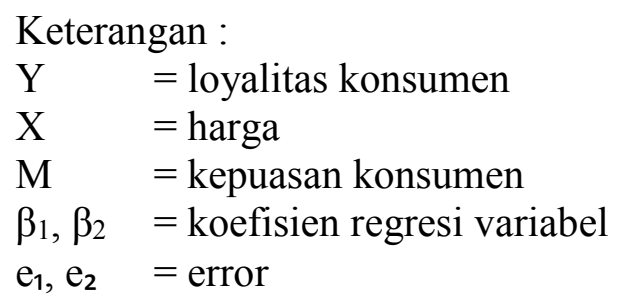

\section{HASIL DAN PEMBAHASAN}

Berdasarkan responden penelitian ini kaum perempuanlah yang mendominasi sebanyak 54\% dan kaum laki-laki sebanyak 34\%. Perbedaan angka tersebut tidak jauh berselisih bahwa bisnis tentang clothing online tidak hanya mengacu pada satu gender saja dan sudah bersifat umum. Bila dilihat dari usianya, usia 18-23 tahunlah yang mendominasi dalam penelitian ini. Disimpulkan bahwa tentang bisnis clothing online ini dapat menarik minat kaum remaja untuk membeli clothing melalui online. Kriteria pendidikan responden yang berpendidikan terakhir SLTA/sederajat mencapai persentase tertinggi yaitu 79\%. Berdasarkan status pekerjaan didomisili oleh Pelajar/SMA.

Uji validitas bertujuan untuk memeriksa apakah kuesioner sebagai instrument penelitian sudah tepat untuk mengukur indikator dalam penelitian. Pernyataan dalam kuesioner dikatakan valid apabila koefisien korelasi $r \geq 0,30$ Sugiyono ( 2017: 178$)$.

Pada Tabel 4. menunjukkan bahwa ketiga instrumen tersebut memiliki koefisien Cronbach's Alpha $>0,60$. Disajikan hasil uji reliabilitas pada Tabel 4 dengan menunjukkan bahwa seluruh instrumen penelitian tersebut mempunyai koefisien cronbach's alpha melebihi 0,60 (reliable), yang dimana variabel harga memiliki cronbach's alpha 0,777; kepuasan konsumen 0,827 dan loyalitas konsumen 0,708 . 
Tabel 3.

Hasil Uji Validitas

\begin{tabular}{cccc}
\hline Variabel & Indikator & $\begin{array}{c}\text { Koefisien } \\
\text { Korelasi }\end{array}$ & Keterangan \\
\hline Harga & $\mathrm{X} 1$ & 0,890 & Valid \\
(X) & $\mathrm{X} 2$ & 0,797 & Valid \\
& $\mathrm{X} 3$ & 0,805 & Valid \\
M1 & 0,847 & Valid \\
Kepuasan Konsumen & $\mathrm{M} 2$ & 0,708 & Valid \\
(M) & $\mathrm{M} 3$ & 0,768 & Valid \\
& $\mathrm{M} 4$ & 0,878 & Valid \\
Loyalitas Konsumen & Y1.5 & 0,676 & Valid \\
(Y) & Y1 & 0,804 & Valid \\
\hline
\end{tabular}

Sumber: Data diolah, 2018

Tabel 4.

Hasil Uji Realibilitas

\begin{tabular}{cccc}
\hline No & Variabel & Cronbach's Alpha & Keterangan \\
\hline 1 & Harga & 0,777 & Reliabel \\
2 & Kepuasan Konsumen & 0,827 & Reliabel \\
3 & Loyalitas Konsumen & 0,708 & Reliabel \\
\hline
\end{tabular}

Sumber : Data diolah, 2018

Tabel 5.

Hasil Uji Normalitas Sub-Struktural 1

\begin{tabular}{lc}
\hline & Unstandardized Residual \\
\hline $\mathbf{N}$ & $\mathbf{8 8}$ \\
\hline $\begin{array}{l}\text { Kolmogrov-Smirnov } Z \\
\text { Asymp.Sig. (2-tailed) }\end{array}$ & 0,200 \\
\hline
\end{tabular}

Sumber : Data diolah, 2018

Berdasarkan Tabel 5. dapat disimpulkan bahwa nilai Kolmogrov-Smirnov Z

Asymp.Sig. (2-tailed) sebesar 0,200 (lebih besar dari alpha 0,05).

Tabel 6.

Hasil Uji Normalitas Sub-struktural 2

\begin{tabular}{lc}
\hline $\mathbf{N}$ & Unstandardized Residual \\
\hline Kolmogrov-Smirnov-Z & $\mathbf{8 8}$ \\
Asymp.Sig. (2-tailed) & 0,200 \\
\hline Sumber : Data diah 2018 & \\
\hline
\end{tabular}

Sumber : Data diolah, 2018

Berdasarkan tabel di atas dapat disimpulkan bahwa nilai Kolmogrov-

Smirnov Z Asymp.Sig. (2-tailed) sebesar 0,200 (lebih besar dari alpha 0,05). 
Tabel 7.

\section{Hasil Uji Multikolinearitas}

\begin{tabular}{llll}
\hline Persamaan Struktur & Variabel & \multicolumn{2}{c}{ Colinearity Statistic } \\
\hline & & Tolerance & VIF \\
\hline $\mathrm{M}=\beta \square \mathrm{X}+\mathrm{e} \square$ & Harga & 1,000 & 1,000 \\
$\mathrm{Y}=\beta \square \mathrm{X}+\beta \square \mathrm{M}+\mathrm{e} \square$ & Harga & 0,313 & 3.191 \\
& Kepuasan Konsumen & 0,313 & 3.191 \\
\hline
\end{tabular}

Sumber : Data diolah, 2018

Berdasarkan Tabel 7. dapat disimpulkan bahwa koefisien tolerance dan VIF dari variabel harga dan kepuasan konsumen menunjukkan nilai tolerance untuk setiap variabel lebih besar dari $10 \%$ dan nilai VIF lebih kecil dari 10 . Hal ini mengindikasikan bahwa tidak ada gejala multikolinearitas dan korelasi dari model regresi yang dibuat sehingga model ini layak untuk memprediksi.

Tabel 8.

Hasil Uji Heteroskedastisitas Sub-struktural 1

\begin{tabular}{|c|c|c|c|c|c|c|}
\hline \multicolumn{7}{|c|}{ Coefficients $^{\mathrm{a}}$} \\
\hline \multirow[b]{2}{*}{ Model } & & \multicolumn{2}{|c|}{ ients } & $\begin{array}{c}\text { Standardized } \\
\text { Coefficients }\end{array}$ & \multirow[b]{2}{*}{$\mathbf{T}$} & \multirow[b]{2}{*}{ Sig. } \\
\hline & & B & Std. Error & Beta & & \\
\hline & (Constant) & 2.640 & 0,553 & & 4.776 & 0,000 \\
\hline & Harga & $-0,044$ & 0,051 & 0,093 & $-0,865$ & 0,389 \\
\hline
\end{tabular}

Sumber : Data diolah, 2018

Berdasarkan hasil perhitungan pada Tabel 8. dapat disimpulkan bahwa nilai Sig. dari variabel harga sebesar 0,389 yang artinya lebih besar dari 0,05 bahwa tidak terdapat pengaruh antara variabel bebas terhadap absolute residual (tidak mengandung adanya gejala heteroskedastisitas).

Tabel 9.

Hasil Uji Heteroskedastisitas Sub-struktural2

\begin{tabular}{|c|c|c|c|c|c|c|}
\hline \multicolumn{7}{|c|}{ Coefficients $^{\mathbf{a}}$} \\
\hline \multirow[b]{2}{*}{ Model } & & \multicolumn{2}{|c|}{ Unstandardized Coefficients } & \multirow{2}{*}{$\begin{array}{c}\begin{array}{c}\text { Standardized } \\
\text { Coefficients }\end{array} \\
\text { Beta }\end{array}$} & \multirow[b]{2}{*}{$\mathbf{T}$} & \multirow[b]{2}{*}{ Sig. } \\
\hline & & $\mathbf{B}$ & Std. Error & & & \\
\hline \multirow[t]{3}{*}{1} & (Constant) & 1.759 & 0,387 & & 4.544 & 0,000 \\
\hline & Harga & $-0,093$ & 0,055 & $-0,324$ & -1.707 & 0,091 \\
\hline & Kepuasan Konsumen & 0,034 & 0,040 & 0,165 & 0,869 & 0,387 \\
\hline
\end{tabular}

a. Dependent Variable: ABSRES1

Sumber : Data diolah, 2018 
Ni Luh Putu Anindya Putri Maharani, Peran Kepuasan Konsumen....

Berdasarkan hasil perhitungan pada Tabel 9. dapat disimpulkan bahwa nilai Sig. dari variabel harga dan kepuasan konsumen masing-masing sebesar 0,091 dan 0,387 yang artinya lebih besar dari 0,05 bahwa tidak terdapat pengaruh antara variabel bebas terhadap absolute residual (tidak mengandung gejala heteroskedastisitas).

Berdasarkan hasil pada Tabel 10. maka persamaan strukturalnya adalah sebagai berikut:

$\mathrm{M}=0,829 \mathrm{X}+\mathrm{e} \square$

Tabel 10.

Hasil Analisis Jalur Sub-struktural 1

\begin{tabular}{|c|c|c|c|c|c|}
\hline \multirow[t]{2}{*}{ Variabel } & \multicolumn{2}{|c|}{ Unstandardized Coefficients } & \multirow{2}{*}{$\begin{array}{c}\text { Standardized } \\
\text { Coefficients }\end{array}$} & \multirow[t]{2}{*}{$\begin{array}{c}\mathbf{t} \\
\text { hitung }\end{array}$} & \multirow[t]{2}{*}{$\begin{array}{l}\text { Sig. } \\
\text { uji t }\end{array}$} \\
\hline & B & $\begin{array}{c}\text { Std. } \\
\text { Error }\end{array}$ & & & \\
\hline (Constant) & 4.959 & 0,908 & & 5.459 & 0,000 \\
\hline Harga (X) & 1.142 & 0,083 & 0,829 & 13,728 & 0,000 \\
\hline R Square & 0,687 & & & & \\
\hline F Statistik & 188.459 & & & & \\
\hline Signifikansi Uji F & 0,000 & & & & \\
\hline
\end{tabular}

Sumber : Data diolah, 2018

Nilai koefisien regresi variabel harga bernilai positif dengan nilai signifikansi uji t kurang dari 0,05. Hal ini menunjukkan bahwa variabel harga memiliki pengaruh positif dan signifikan terhadap variabel kepuasan konsumen. Besarnya pengaruh variabel bebas terhadap variabel terikat yang ditunjukkan oleh nilai determinasi total (R square) sebesar 0,687 mempunyai arti bahwa sebesar 68,7\% variasi kepuasan konsumen dipengaruhi oleh variasi harga, sedangkan sisanya sebesar 31,3\% dijelaskan oleh faktor lain yang tidak dimasukkan kedalam model. 
Tabel 11.

Hasil Analisis Jalur Sub-struktural 2

\begin{tabular}{lccccc}
\hline \multicolumn{1}{c}{ Variabel } & \multicolumn{2}{c}{$\begin{array}{c}\text { Unstandardized } \\
\text { Coefficients }\end{array}$} & $\begin{array}{c}\text { Standardized } \\
\text { Coefficients }\end{array}$ & t hitung & $\begin{array}{c}\text { Sig. uji } \\
\text { t }\end{array}$ \\
\hline B & Std. Error & Beta & & \\
\hline Harga (X) & 0,484 & 0,659 & & 0,734 & 0,465 \\
Kepuasan Konsumen (M) & 0,562 & 0,093 & 0,593 & 6.053 & 0,000 \\
R Square & 0,210 & 0,067 & 0,305 & 3.112 & 0,003 \\
F Statistik & 0,744 & & & & \\
Signifikansi Uji F & 123.728 & & & & \\
\hline Sumber : Data diolah, 2018 & 0,000 & & & &
\end{tabular}

Berdasarkan hasil pada Tabel 11. maka persamaan strukturalnya adalah sebagai berikut:

$\mathrm{Y}=0,593 \mathrm{X}+0,305 \mathrm{M}+\mathrm{e} \square$

Nilai koefisien regresi masing-masing variabel bebas bernilai positif dengan nilai signifikansi uji t kurang dari 0,05 . Hal ini menunjukkan bahwa semua variabel bebas memiliki pengaruh positif dan signifikan terhadap variabel terikat. Besarnya pengaruh variabel bebas terhadap variabel terikat yang ditunjukkan oleh nilai determinasi total (R Square) sebesar 0,744 mempunyai arti bahwa sebesar 74,4\% variasi loyalitas konsumen dipengaruhi oleh variasi harga dan kepuasan konsumen, sedangkan sisanya sebesar $25,6 \%$ dijelaskan oleh faktor lain yang tidak dimasukkan ke dalam model.

Menguji nilai koefisien determinasi $\left(\mathrm{R}^{2}\right)$ dari variabel error (e). Berdasarkan model substruktur di atas, maka dapat disusun model diagram jalur akhir. Sebelumnya, terlebih dahulu hitung nilai standar error sebagai berikut:

$$
\begin{aligned}
& \mathrm{e}=\sqrt{1-R^{2}} \ldots \ldots \ldots \ldots \ldots \ldots \ldots \ldots \ldots \\
& \mathrm{e}_{1}=\sqrt{1-R 1^{2}}=\sqrt{1-0,687}=0,559 \\
& \mathrm{e}_{2}=\sqrt{1-R 2^{2}}=\sqrt{1-0,744}=0,505
\end{aligned}
$$


Berdasarkan perhitungan pengaruh error $\mathrm{Pe} \square$, didapat hasilnya sebesar 0,727 dan pengaruh eror Pe $\square$ sebesar 0,505. Hasil koefisien determinasi total adalah sebagai berikut:

$$
\begin{aligned}
\mathrm{R} 2 \mathrm{~m} & =1-(\operatorname{Pe} 1)^{2}(\mathrm{Pe} 2)^{2} \ldots \ldots \\
& =1-(0,559)^{2}(0,505)^{2} \\
& =1-(0,312)(0,255) \\
& =1-0,079 \\
& =0,921
\end{aligned}
$$

Nilai determinasi total sebesar 0,921 yang artinya sebesar $92,1 \%$ variasi loyalitas konsumen dipengaruhi oleh variasi harga dan kepuasan konsumen, sedangkan sisanya sebesar 7,9\% dijelaskan oleh faktor yang lain yang tidak dimasukkan ke dalam model penelitian ini.

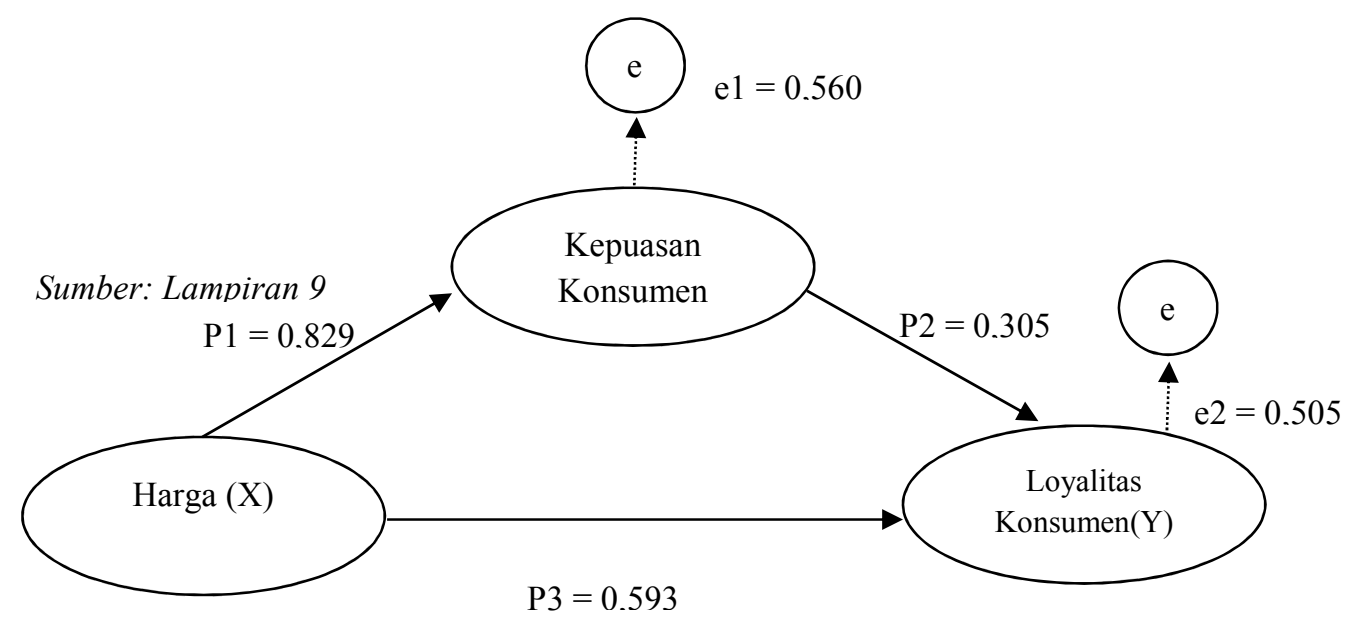

\section{Gambar 2.Validasi Model Diagram Jalur Akhir}

Berdasarkan model diagram jalur pada Gambar 2 dapat dihitung besarnya pengaruh langsung dan tidak langsung serta pengaruh keseluruhan antar variabel. 
Tabel 12.

Pengaruh Langsung dan Pengaruh Tidak Langsung serta Pengaruh Total Harga (X), Kepuasan Konsumen (M), dan Loyalitas Konsumen (Y).

Tabel 12. menunjukkan bahwa pengaruh langsung harga $(\mathrm{X})$ terhadap kepuasan konsumen (M) adalah sebesar 0,829. Pengaruh langsung variabel harga (X) terhadap loyalitas konsumen (Y) adalah sebesar 0,593. Pengaruh langsung variabel kepuasan konsumen (M) terhadap loyalitas konsumen (Y) sebesar 0,305. Hal ini menandakan bahwa variabel kepuasan konsumen lebih besar dipengaruhi oleh daripada harga . Adapun pengaruh tidak langsung variabel harga $(\mathrm{X})$ terhadap loyalitas konsumen (Y) melalui kepuasan konsumen (M) adalah sebesar 0,845. Jadi dapat disimpulkan bahwa lebih besar total pengaruh harga $(\mathrm{X})$ terhadap loyalitas konsumen (Y) yang melalui kepuasan konsumen (M), daripada pengaruh langsung harga terhadap loyalitas konsumen tanpa melalui kepuasan konsumen.

Tabel 13.

\section{Hasil Uji Sobel}

\begin{tabular}{lll}
\hline Sobel & Nilai & Keterangan \\
\hline$Z$ & 2.849 & Memediasi \\
Sig. & 0,000 & Signifikansi \\
\hline Sumber $:$ Data diolah, 2018 & &
\end{tabular}

$\mathrm{Sab}=\sqrt{a^{2} S b^{2}+b^{2} S a^{2}+S a^{2} S b^{2}}$

Keterangan :

$\mathrm{a}=1,142$

$\mathrm{Sa}=0,083$

$\mathrm{b}=0,210$

$\mathrm{Sb}=0,067$

$\mathrm{Sab}={\sqrt{1,142^{2} 0,067}}^{2}{\overline{+0,201^{2} 0,083^{2}}}^{2}$

$=\sqrt{0,000304+0,005854+0,000923}$

$=\sqrt{0,007081}$ 


$$
\begin{aligned}
& =0,084 \\
Z & =\frac{a}{S a b} \ldots \\
& =\frac{0,239}{0,084} \\
& =2,85
\end{aligned}
$$

Berdasarkan hasil dari Tabel 13. dapat disimpulkan bahwa nilai Z sebesar 2.85 yang artinya nilai ini lebih besar dari nilai yang ditentukan yaitu 1,96 dengan tingkat signifikansi 0,000. Hal ini menunjukkan bahwa variabel kepuasan konsumen mampu memediasi variabel harga terhadap kepuasan konsumen. Salah satu tujuan dari penelitian ini yaitu untuk mengetahui secara empiris pengaruh harga terhadap loyalitas konsumen. Berdasarkan hasil uji hipotesis, terbukti bahwa harga berpengaruh positif dan signifikan terhadap loyalitas pelanggan. Harga yang tetap yang diberikan oleh clothing online membuat responden merasa bahwa mereka lebih baik berbelanja di clothing online. Kegiatan jual-beli online menjadi menyenangkan. Syarat pembayaran pada clothing online juga sangat jelas sehingga para pelanggan mudah menggunakannya.

Hal ini juga mendukung penelitian Loyalitas konsumen yang berlanjut dirasakan oleh pelanggan selama masih merasakan bahwa ia sudah menerima nilai yang baik dari suatu produk, termasuk kualitas yang lebih tinggi dalam kaitanya dengan harga dibandingkan dengan yang diperoleh (Lovelock, 2007:133). Didukung oleh penelitian (Ria Syaputri, 2015) yang menyatakan bahwa harga berpengaruh positif terhadap terbentuknya loyalitas pelanggan. Hasil penelitian yang menyatakan bahwa terdapat pengaruh positif antara harga terhadap loyalitas pelanggan supermarket Sri Ratu Peterongan, populasi dalam penelitian ini adalah seluruh pelanggan Supermarket Sri Ratu Peterongan, 
sampel dalam penelitian ini berjumlah 100 orang, teknik analisis data yang digunakan yaitu analisis regresi linier berganda Bebet Wijayanto (2013). Berdasarkan penelitian yang dilakukan oleh (Nurhayati, 2011) semakin harga suatu produk atau jasa sesuai dengan kualitas suatu produk atau jasa tersebut maka kepuasan yang dirasakan pelanggan akan semakin tinggi dan semakin loyal pelanggan tersebut. Penelitian ini dilakukan di Semarang, yang dimana sampel berjumlah 100 orang.

Hal ini juga mendukung hasil penelitian yang dilakukan oleh Albertus (2012) menyatakan adanya pengaruh harga terhadap kepuasan konsumen dengan hasil yang mengatakan bahwa konsumen puas dengan harga yang relatif tidak murah namun sesuai dengan kualitas dari produk tersebut. Penelitian yang dilakukan oleh (Aprilia, 2013) juga menyatakan bahwa harga berpengaruh positif terhadap kepuasan pelanggan.

Pada tingkat harga tertentu, jika manfaat yang dirasakan meningkat, maka nilainya akan meningkat pula. Apabila nilai yang dirasakan pelanggan semakin tinggi, maka akan menciptakan kepuasan pelanggan yang maksimal. Penelitian ini sejalan dengan yang dilakukan (Dedi Kurniawa, 2015) yang mengatakan bahwa harga berpengaruh signifikan terhadap kepuasan konsumen.

Salah satu tujuan dari penelitian ini yaitu untuk mengetahui secara empiris pengaruh kepuasan konsumen terhadap loyalitas konsumen. Berdasarkan hasil uji hipotesis terbukti bahwa kepuasan pelanggan berpengaruh positif dan signifikan terhadap loyalitas pelanggan. Loyalitas sangat penting dalam keberlangsungan perusahaan karena jika konsumen puas, maka keloyalan konsumen terhadap produk 
yang ditawarkan, maka perusahaan juga akan mendapatkan keuntungan. Pembeli juga akan lebih sering berbelanja pada clothing online.

Hal ini juga mendukung hasil penelitian yang menyatakan bahwa kepuasan pelanggan berpengaruh terhadap loyalitas pelanggan yang dilakukan oleh (Ashgarian et al. 2012) menyatakan bahwa kepuasan pelanggan berpengaruh positif terhadap loyalitas pelanggan. Di dalam jurnal ini meneliti tentang kualitas produk, citra perusahaan, kepuasan konsumen dan loyalitas konsumen hijau.

Konsumen akan setia atau loyal terhadap suatu merek bila konsumen mendapatkan kepuasan dari merek tersebut. Meningkatkan kepuasan pelanggan, perusahaan tersebut perlu mengatur strategi pemasaran agar konsumen tertarik terhadap produk-produk yang ditawarkan. Apabila produk tersebut memberi kepuasan bagi konsumen, maka konsumen akan tetap setia menggunakan merek tersebut dan berusaha untuk membatasi pembelian produk lain (Aryani dan Rosinta, 2010). Pelanggan yang sangat puas atau bahkan menyenangi layanan cenderung menjadi pendukung loyal perusahaan dan menyebar berita positif. Ketidakpuasan sebaliknya menjauhkan pelanggan dan menjadi faktor penentu dalam perilaku beralih (Lovelock et al., 2013).

Salah satu tujuan dari penelitian ini yaitu untuk mengetahui secara empiris pengaruh kepuasan konsumen dalam memediasi hubungan harga terhadap loyalitas konsumen. Hasil uji hipotesis dalam penelitian ini menunjukkan bahwa kepuasan konsumen dalam memediasi hubungan harga berpengaruh positif dan signifikan terhadap loyalitas konsumen. Hal ini dibuktikan dengan seseorang jika merasa puas berbelanja pada clothing online maka mereka akan mengajak teman-temannya 
untuk berbelanja pada clothing online yang sama. Pengguna merasakan kepuasan terhadap harga yang diberikan dan mereka juga menilai kualitas pelayanan yang diberikan sangat baik sehingga menimbulkan sikap loyal.

Hal ini juga mendukung penelitian menurut (Subagio dan Harianto, 2013) menyebutkan bahwa faktor yang memepengaruhi kepuasan dan loyalitas pelanggan adalah brand dan harga. Hasil penelitian yang menyatakan tentang pengaruh harga dan kualitas pelayanan terhadap loyalitas pelanggan melalui variabel kepuasan (Kurniasih, 2012). Penelitian ini dilakukan di Siliwangi, Semarang dengan jumlah populasi sebanyak 18.123 pelanggan.

Hasil penelitian yang meneliti tentang analisis pengaruh kualitas pelayanan, harga dan kepuasan pelanggan terhadap loyalitas pelanggan. Penelitian ini dilakukan di Semarang dengan jumlah populasi pelanggan tetap yang dimiliki pada periode tahun 2009-2011 adalah sebanyak 115 pelanggan (Febri dan Edy, 2012). Jadi, dari penelitian sebelumnya ditemukan bahwa harga berpengaruh terhadap loyalitas, harga berpengaruh terhadap kepuasan konsumen dan kepuasan konsumen berperan sebagai variabel intervening antara harga dan loyalitas pelanggan.

\section{SIMPULAN DAN SARAN}

Berdasarkan hasil analisis data, kesimpulan penelitian ini dapat dikemukakan sebagai berikut harga berpengaruh positif dan signifikan terhadap loyalitas konsumen. Pengaruh positif ini memberikan makna bahwa konsumen akan loyal jika perusahaan menetapkan harga produk yang sebanding dengan manfaat yang diberikan kepada konsumen dan harga berpengaruh positif dan signifikan terhadap kepuasan konsumen. Pengaruh positif ini memberikan makna bahwa setiap kali 
konsumen mengevaluasi nilai layanan yang diperoleh, mereka menentukannya berdasarkan harga.

Kepuasan pelanggan berpengaruh positif dan signifikan terhadap loyalitas pelanggan. Pengaruh positif ini memberikan makna bahwa loyalitas sangat penting dalam keberlangsungan perusahaan karena jika konsumen puas, maka keloyalan konsumen terhadap produk yang ditawarkan maka perusahaan juga akan mendapat keuntungan dari apa yangsudah ditawarkan pada konsumen dan kepuasan konsumen mampu memediasi pengaruh harga terhadap loyalitas pelanggan. Pengaruh positif ini memberikan makna bahwa harga berpengaruh terhadap loyalitas harga berpengaruh terhadap kepuasan konsumen dan berperan sebagai variabel intervening antara harga dan loyalitas pelanggan.

Berdasarkan hasil penelitian yang menunjukkan bahwa konsumen cenderung melakukan pembelanjaan kembali dengan niat yang cukup tinggi, sehingga disarankan clothing online untuk mempertahankan kualitas produk yang meningkatkan minat konsumen akan berbelanja kembali melalui Instagram pada clothing online yang sama, misalnya dengan mempertahankan kualitas dari bahan tersebut.

\section{REFRENSI}

Albertus. (2012). "Analisis Pengaruh Harga, KualitasProduk, Dan Kualitas Layanan Terhadap KepuasanPelanggan"Fakultas Ekonomi dan Bisnis Universitas Diponegoro. Jurnal Ekonomi, vol 1(01). Hal 1-9.

Aprilia. (2013). “Analisis Pengaruh Kualitas Pelayanan,Harga, dan Promosi Terhadap KepuasanPelanggan” Fakultas Ekonomi dan BisnisUniversitas Diponegoro. Jurnal Ekonomi, vol 2(01).

Asgharian R; M. Salehi, Z. S; Salehi, R. Hojabri, \& M. Nikkheslat. (2012). Green Product Quality, green customer satisfaction, and green customer loyalty, 
International Journal of Research in Management \& Technology (IJRMT), vol 2( 5), pp. 499-503.

Aryani, Dwi \& Febrina Rosinta. (2010). Pengaruh Kualitas Layanan terhadap Kepuasan Pelanggan dalam Membentuk Loyalitas Pelanggan, Jurnal Ilmu Administrasi dan Organisasi, vol 17(22), h: 114-126.

Amir Mahmud ;Kamaruzaman Jusoff and St. Hadijah. (2013). The Effect of Service Quality and Price on Satisfaction and Loyalty of Customer of Commercial Flight Service Industry. World Applied Sciences Journal, vol 23(3), 354-359.

Buchari,Alma.(2011). Manajemen Pemasaran dan Pemasaran Jasa. Bandung : Alfabeta.

Bps.go.id https://bali.bps.go.id/statictable/2018/04/13/95/persentase-pendudukusia-5-tahun-ke-atas-yang-mengakses-teknologi-informasi-dan-komunikasitik-dalam-3-bulan-terakhir-menurut-kabupaten-kota-2017.html. Diakses pada 9 juli 2018.

Daryanto, dan I. Setyobudi. (2014). Konsumen dan Pelayanan Prima. Yogyakarta: Gava Media.

Demirci, Ahmet E. \& Nezihe Figen E. (2008). Technology Readiness for Innovative High-Tech Products: How Consumers Perceive and Adopt New Technologies, The Business Review, vol. 1(1).

Elvandari, S. D. (2011). Penerimaan Sistem Online Berdasarkan Unifield Theory of Acceptance and Usage of Technology. Jurnal Integral, vol 1(1) 72-91.

Ekawati, Ni Wayan; Rahyuda, I Ketut; Kerti Yasa, Ni Nyoman dan Sukaatmaja, I Putu Gde. (2016). The Implementation of Ecopreneurship and Green Innovation in Building Competitive Advetage to Generate Succes of New Spa Products in Bali. International Business Management.vol 10 (14): pp: 26602669.

Fandy Tjiptono. (2016). Strategi Pemasaran. Yogyakarta : Penerbit ANDI.

Febri \& Edy. (2012). Pengaruh Kualitas Pelayanan, Harga dan Kepuasan Pelanggan Terhadap Loyalitas Pelanggan Di Bengkel Mobil Rapiglass Autocare Semarang, Diponegoro Journal of Management, vol. 1(1).

Ismail Razak, Nazief Nirwanto dan Boge Triatmanto. (2016). The Impact of Product Quality and Price on Customer Satisfaction With The Mediator of Customer Value. Journal of Marketing and Consumer Research, vol 30, 2422-8451. 
Kurniasih, Indah Dwi. (2012). Pengaruh Harga dan Kualitas Pelayanan Terhadap Loyalitas Pelanggan Melalui Variabel Kepuasan (Studi Pada Bengkel Ahass002 Astra Motor Siliwangi Semarang), Jurnal Administrasi Bisnis, Vol. 1, No. 1.

Kotler, Philip \& Keller, (2007), Manajemen Pemasaran, Jilid I, Edisi Kedua belas, PT. Indeks, Jakarta.

Kotler, Philip.\& Gery, A. (2012). Principles of Marketing. Pearson Education Limited. New Jersey.

Lupiyoadi, R. (2011).Manajemen Pemasaran Jasa Teori dan Praktik. Salemba Empat.

Lovelock, Christhoper. (2007). Manajemen Pemasaran Jasa cetakan ke-2. Indeks

Lovelock, Christhoper; Wirtz J., dan Mussry., J., (2013). Pemasaran Jasa Jilid 2. Jakarta: Erlangga.

Meskaran, F; Ismail. Z. dan Shanmugam. B. (2013).’Online Purchase Intention: Effects of Trust and Security Perception". Australian Journal of Basic and Applied Sciences, vol 7(6) pp. 307-315.

Moraga; Eduardo Torres ;Arturo Z. Vasques Parraga and Jorge Zamora Gonzales. (2008). Customer Satisfaction and Loyalty : Start Wih The Product, Culmite With The Brand. Journal of Customer Marketing, vol 25(5), pp. 302-313.

Nurhayati, Risky. (2011). Pengaruh Kualitas Produk dan Harga terhadap Kepuasan Pelanggan, Skripsi Administrasi Bisnis Fakultas Ilmu Sosial dan Politik Universitas Veteran Yogyakarta.

Noor Hafiza Mohammed; Sholehah Abdullah; Suzila Mat Salleh; Kartini Mat Rashid; Siti Fatimah Mardiah Hamzah \& Najmiah Sudin. (2017). Relationship among Service and Product Quality, and Price in Establishing Customer Satisfaction. Journal of Applied Environmental and Biological Sciences. Vol 7(5), 45-50.

Oliver dan Onyancha G.,K. (2013). The Impact of Bank Brand Image on Customer Satisfaction and Loyalty: A Case of Kenya Commercial Bank. European Journal of Business and Management ISSN 2222-1905 (Paper) ISSN 22222839 (Online), vol 5 (21).

Rocketmanajemen. (2016). Instagram vs Facebook Untuk Jualan Bagus Mana?.Rocketmanajemen[online],Tersedia:http://rocketmanajemen.com/ju alan-lewat-facebook-atau-instagram-bagusmana/. Diakses pada tanggal 22 November 2016. 
Sangadji, E. M., \& Sopiah. (2013). Perilaku Konsumen - Pendekatan Praktis Disertai Himpunan Jurnal Penelitian.Yogyakarta. Andi

Setyawati, S.,M., \& Rosiana, M., (2015). Inovasi Dan Keunggulan Kompetitif Sebagai Variabel Mediasi Pengaruh Orientasi Pasar Terhadap Kinerja Bisnis (Studi Empiris Pada Usaha Kecil Dan Menengah Di Purwokerto). Jurnal Fakultas Ekonomi dan Bisnis Universitas Jenderal Soedirman, vol 5 (1):318.

Sedjai Asma; Maliki Samir Baha Dine; Berbar Wafaa dan Ainous Redouan. (2018). The Effect of Perception Quality/Price of Service on Satisfaction and Loyalty Algerians Customers Evidence Study Turkish Airlines. International Journal Economic Management Sci, vol 7(1), 2162-6359.

Schiffman, L.G. \& Kanuk. L. L. (2008). Perilaku Konsumen, Edisi Ketujuh. Jakarta: PT Indeks.

Subagio \& Harianto.(2013). Analisa Pengaruh KualitasLayanan, Brand Image, Dan AtmosferTerhadap Loyalitas Konsumen DenganKepuasan Konsumen Sebagai VariabelIntervening Konsumen Kedai Deja-VuSurabaya. Jurnal Strategi Pemasaran. vol. 1,No. 1, 1-8

Sunyoto, D. (2014). Konsep Dasar Riset Pemasaran dan Perilaku Konsumen. Yogjakarta: CAPS (Center dor Academic Publishing Service).

Sugiyono. (2017). Metode Penelitian Pendidikan (Pendekatan Kualitatif, Kuantitatif, dan $R \& D$ ). Bandung: Alfabeta.

Tjiptono, F. (2011). Pemasaran Jasa. Bayumedia Publishing. Yogyakarta.

Tjiptono, F. (2006). Strategi Pemasaran . Edisi X. Andi Offset. Yogyakarta.

Wahyuno, Cahyo. (2013). Pengaruh Kualitas Pelayanan dan Harga terhadap Kepuasan Konsumen Pengguna Jasa Hotel Anugerah Glagah Indah Temon Kulon Progo Yogyakarta. Skripsi Tidak Diterbitkan. Yogyakarta: FE UNY.

Wagner, K. (2015). Instagram is the fastet growing major social network.http://recode.net/2015/01/09/instagram-is-the-fastet-growingmajor-social-network/. Diakses tanggal 28 Februari 2018

Witriyanti, P.A.M. (2016). Aplikasi Model TAM (Technology Acceptance Model) Terhadap Perilaku Pengguna Instagram, Fakultas Ekonomi dan Bisnis Universitas Udayana (UNUD), Bali, Indonesia.

www.ipsos-na.com.http://salingsilang.com/baca/tertinggi-di-dunia-penggunainternet-indonesia-yang-aktif-di-media-sosial (Diakses 24 Maret 2012). 